\title{
Tribbles Homolog 2
}

National Cancer Institute

\section{Source}

National Cancer Institute. Tribbles Homolog 2. NCI Thesaurus. Code C104577.

Tribbles homolog 2 (343 aa, $\sim 39 \mathrm{kDa}$ ) is encoded by the human TRIB2 gene. This protein is involved in the modulation of MAP kinase activation. 